Article

\title{
Non-Destructive Techniques for Building Evaluation in Urban Areas: The Case Study of the Redesigning Project of Eleftheria Square (Nicosia, Cyprus)
}

\author{
Marilena Cozzolino ${ }^{1, *(D)}$, Vincenzo Gentile ${ }^{1}$, Paolo Mauriello ${ }^{1}$ and Agni Peditrou ${ }^{2}$ \\ 1 Department of Human, Social and Educational Science, University of Molise, Via De Sanctis, \\ 86100 Campobasso, Italy; vincenzo.gentile86@gmail.com (V.G.); mauriello@unimol.it (P.M.) \\ 2 Architectural Planning Office, Nicosia Municipality, Eptanisou 11, 1016 Nicosia, Cyprus; \\ Agni.Petridou@nicosiamunicipality.org.cy \\ * Correspondence: marilena.cozzolino@unimol.it
}

Received: 1 June 2020; Accepted: 16 June 2020; Published: 23 June 2020

check for updates

\begin{abstract}
This paper deals with the application of non-destructive geophysical techniques of investigation in the urban environment of the city of Nicosia (Cyprus). The main aim of the research was, in the frame of the Eleftheria Square redesign project, to image subsurface properties in order to reduce the impact of hazards on the old buildings (therefore preserving the cultural heritage of the place), and on the new infrastructure under construction. Since 2008, electrical resistivity tomography (ERT), ground penetrating radar (GPR) and induced electromagnetic method (EMI) were employed during the different phases of the project to provide an understanding of geological stratigraphy, the detection of buried objects (archaeological structures and underground utilities) and the solution of unexpected events (such as water infiltration in the course of works). The geophysical results proved the efficiency of the adopted methods, adding scientific value to the knowledge of the studied area. The new gathered information helped the public administration technicians to plan direct and targeted interventions and to modify the original design of the project according to the discovery of archaeological findings.
\end{abstract}

Keywords: applied geophysics; urban geophysics; Eleftheria Square; ERT; probability-based ERT inversion (PERTI) method; GPR; EMI

\section{Introduction}

Applied geophysics, through the employment of different methodologies, represents a useful tool to map subsurface features in a non-invasive way, and up to date, successful documented researches in rural settings dealing with different research objectives are available in the literature. Geological investigations for characterizing faults [1-3], landslides [4,5], paleo-morphologies [6,7], litho-stratigraphies [8,9], acquifers [10], sinkoles [11,12], and seepage detection [13] are generally carried out through electrical resistivity tomography (ERT) $[1-3,5,7,9]$, ground penetrating radar (GPR) $[8,10]$, seismic [2,4-6], magnetic [14-17] and gravity [18] methods. Archae-geophysical prospections are particularly common in applications for the detection of buried structures, tombs, and channels through the application of electromagnetic methods [19,20], magnetometry [21], ERTs [22,23], GPR [24,25] or the combination of them. The diagnostics and the monitoring of buildings in architectural and engineering surveys are often reached by implementing linear variable displacement transducer [26], sonic tomography [27], infrared thermography [27-29] and GPR [30-32] because of the high resolution of results.

In contrast, the geophysical exploration in urban environments for different purposes is currently in constant development. The consistent noise, the low signal-to-noise ratio, the reduced spaces to operate 
in, and the presence of paved surfaces, asphalt or complex layers disturbed by anthropological buried shallow artifacts and metallic structures represent a problematic difficulty in geophysical prospections that can significantly influence data quality. The rising interest of those aspects are evidenced by the inclusion of the matter in ad-hoc sessions of international workshops and conferences [33-36] and by the increment of special issues of international journals aiming to provide an enrichment of showcases for urban geophysics [37-39]. Nevertheless, some applications can be found in current literature, providing information on cavity individuation [40], geological mapping [41,42], archaeological investigations [43-45] and underground pipe detection [46,47].

In this work, ground-sensing prospections were used to characterize the subsurface in the areas involved in the redesign project of Eleftheria Square (Nicosia, Cyprus) (Figure 1).
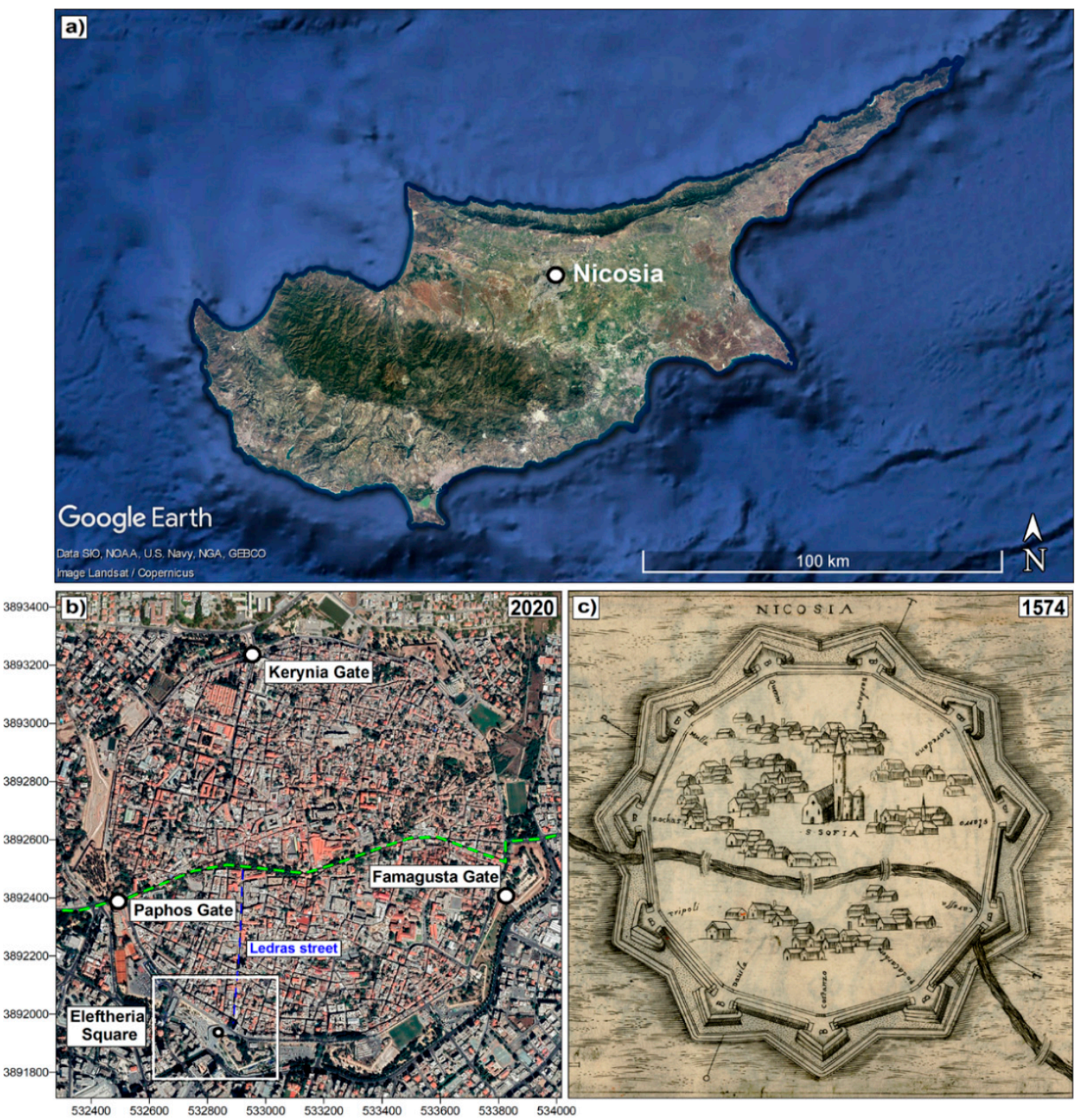

Figure 1. Location of Nicosia on a Google Earth ${ }^{\mathrm{TM}}$ satellite image (2020) of Cyprus (a), the historical center of Nicosia (Cyprus) with the indication of the three gates, Eleftheria Square and the surrounding area, the Green Line (the border line that separates the island and the city in two parts) and the main Ledras Street (b) and an ancient map enhancing the Venetian walls [48] (c).

The activities lasted more than ten years, from 2008 until today; the geophysical studies were an integral part of the project and here we report the various steps. The action was performed in the framework of a collaboration between University of Molise and the Nicosia Master Plan and was partly supported by the Ministry of Foreign Affairs. In particular, the research was in the frame of a scientific 
archaeological mission that had not only the function of scientific study but also represented a valuable tool for intercultural dialogue and development policies in the host country. The archeo-geophysical surveys performed at Famagusta Gate, Castellionissa Hall, Phafos Gate, the monumental complex of the Bedestan and Plateia Di Marche are within this project $[49,50]$. The choice of Eleftheria Square as a study case is justified by the majesty and prestige of the construction project. In addition, as it provided for a distortion of the original setting with an enormous impact on its soils, the landscape and the urban system, there was the real need to acquire information before direct interventions.

In this case, a careful evaluation of the best method to implement to solve a particular problem was carried out and the ERT, GPR and induced electromagnetic (EMI) techniques were used in this contest. Sometimes investigations were conducted in an emergency situation by providing quick answers directly on the investigation site for problem solving.

According to the architectural work being planned, the surveys were organized during the executive phases of the intervention with the following aims:

- Evaluation of the potential risk of presence of archaeological remains, and consequently their hazard of destruction, at Eleftheria Square (Survey 1 in Figure 2) and Solomon Square (Survey 2 in Figure 2) in 2008, before the beginning of the construction of the new structure.

- Delineation of the geological stratigraphy of the soil proving the absence of cavities or archaeological structures in function of the construction of the underground car parking along Amirou Avenue in 2009 (Survey 3 in Figure 2).

- Detection of underground utilities with the aim to facilitate technicians' work during excavation and avoid unexpected damages to city supplies along Amirou Avenue in 2017 (Survey 4 in Figure 2).

- Comprehension of the reason for an abundant flow of water that occurred inside the new underground electrical substation positioned under the new Eleftheria Square during excavations at the intersection of Evagorou Avenue and Omirou Avenue in 2009 (Survey 5 in Figure 2). The most reliable hypothesis of the cause of this phenomenon was thought to be the failure of water pipes south of Evagorou Avenue.

From a scientific point of view, we wanted to show, through the chosen case study, the efficiency of this type of investigation in very disturbed environments such as an urban context where stratigraphies are often disturbed by recent or ancient buried anthropogenic elements. In particular, for ERT data processing, this was the opportunity to test the probability-based ERT inversion (PERTI) method [51], applied here for the first time to model near-surface urban geoelectrical data. The algorithm was developed contextually with needs that the case study presented, having, among its main features, a good filter capacity and the possibility of performing real-time inversion directly in the field, thus allowing for fast modifications of the survey plan to better focus on the expected targets [51].

In the following sections, a brief description of the case study and its cultural value is given, then the methodological approach to the research is explained and the results are reported and discussed. 


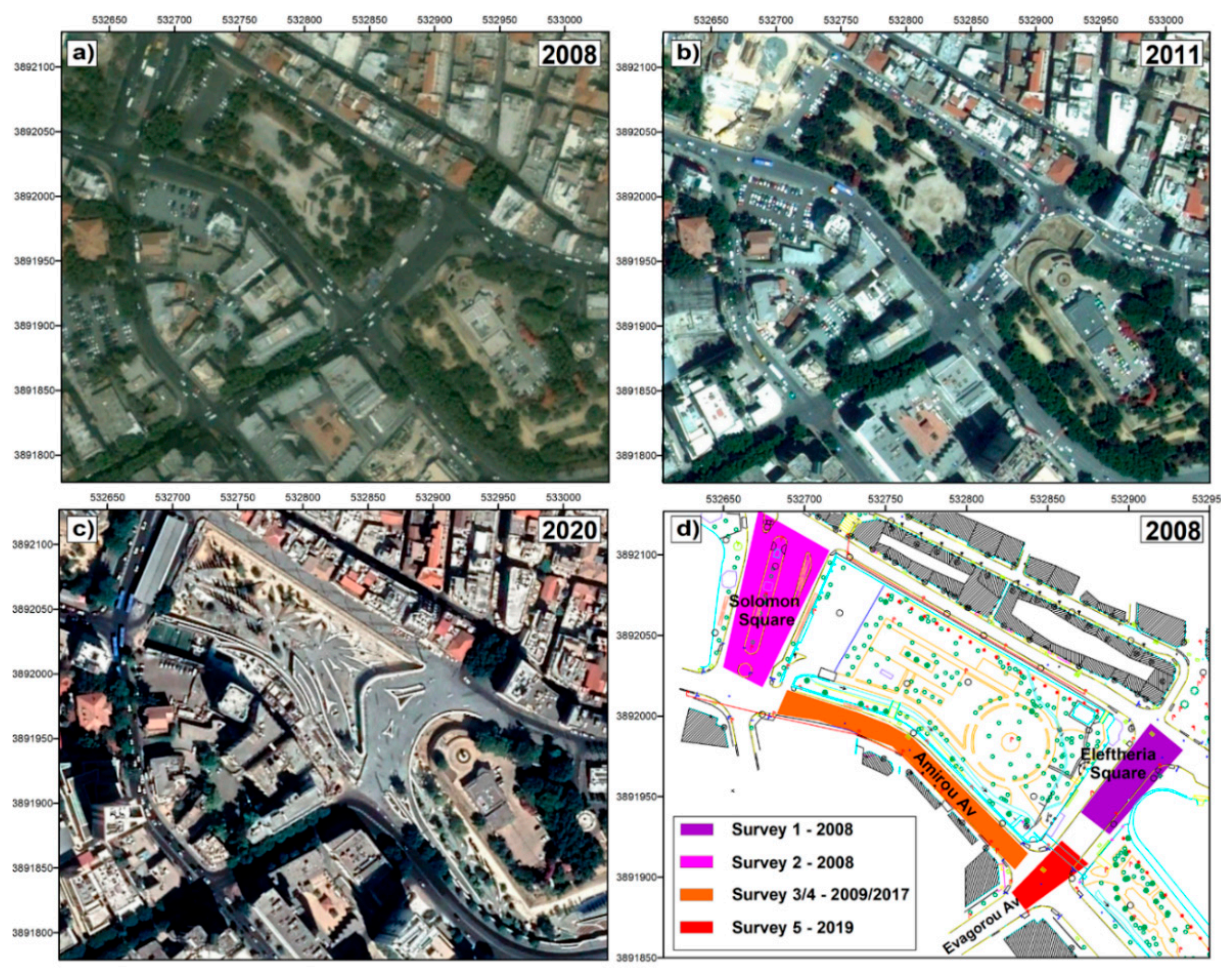

Figure 2. Google Earth ${ }^{\mathrm{TM}}$ satellite images $(2008,2011,2020)$ of Eleftheria Square and surrounding areas $(\mathbf{a}-\mathbf{c})$ and location of geophysical surveys $(\mathbf{d})$.

\section{Case Study}

Nicosia has been the capital of Cyprus since the 10th century. During the Middle Ages, walls larger than the actual fortification were built to protect the city. The engineer Giulio Savorgnano designed the Venetian walls that subsist today during the Venetian period (1489-1570) for defense from Ottoman attacks. They have a circular shape containing eleven pentagonal bastions and incorporate specific innovative military architecture (Figure 1). The fortification had three gates known today as Famagusta Gate, Paphos Gate and Kerynia Gate (Figure 1a). At the end of the 19th century, the city began to expand towards the southwest direction outside of the walls and new openings were realized by constructing bridges over the moat connecting the old town with the surrounding areas. The main square of Eleftheria Square today is located at the site of one of the first openings that was created on the walls towards the end of the 19th century in order to facilitate the direct connection of the old city with the newly developed areas around the walls (Figure 3). In 1882, a bridge in wood was built but later it was substituted with an in-filled solid bridge with stone walls. In 1930 during the English regime, the passage was widened while demolishing part of the bastion of the Venetian walls. The square has been a timeless gathering place for citizens linked to important historical moments of the country and the major celebrations of the capital city.

In 1974, the Turks invaded the island, occupying the 37\% of it. The so-called "Green Line" (Figure 1a) separates the island in two parts; crossing the city of Nicosia actually represents today the unique divided capital in Europe. Due to this division, the historic city center suffered from depopulation, significant physical decay, loss of commercial activities and employment, and high concentration of social problems [52,53]. Since April 2003, it was possible to cross the Green Line and move between the two regions. In 2008, the first passage was unlocked inside the historical center of the capital through Ledra Street (Figure 1a).

In 1979, a significant agreement was reached between the Turkish and Cypriot community in order to prepare a bi-communal master plan with the aim to improve current and future living conditions for all residents of Nicosia. The Nicosia Master Plan was put under the auspices and the 
financial backing of the United Nations Development Programme (UNDP), incorporating the following objectives [53,54]:

- Social rehabilitation of old residential quarters, community development and population increase;

- Economic revitalization and increase of employment activities;

- Restoration of monuments and buildings, preserving culture heritage and increasing the potential tourism attraction;

- Overall urban planning for a harmonic and balanced development of different sectors of the historic center.
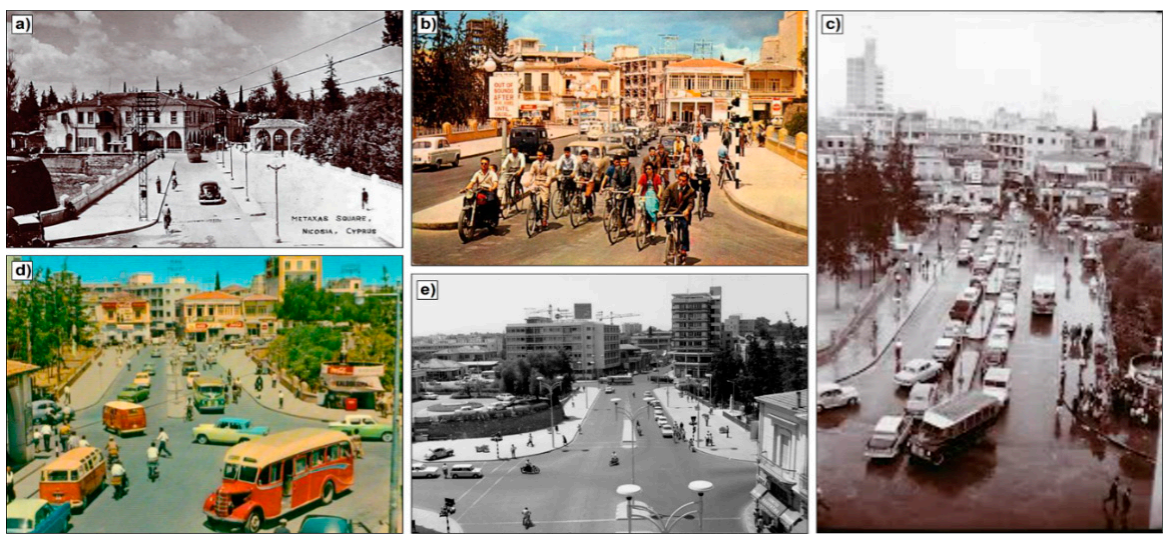

Figure 3. Photographs of Eleftheria Square (Metaxa Square) in 1945 (Photo captured by J. Arthur Dixon) (a,b), 1957 (Photo captured by Felix Giaxis) (c), 1950 (d) and 1969 (e).

Thus, in the last decades the town has witnessed the growth of projects focusing on restoring historic buildings, preserving cultural heritage, and calling for new constructions in the periphery and along the historic fortification walls. An example is testified by the renovation of Elefteria Square, an important link between the old town and the modern city outside the walls. In 2005, an architectural competition assigned the project to Zaha Hadid Architects, an architectural office of international reputation, that proposed a modern solution which was blending the Venetian walls, the ditch and the limits between the two parts of the city [55] (Figure 4). The project, directed by Christos Passas, transformed the moat into a green park in combination with the restored Venetian walls, offering recreational facilities, spaces to be used for sport and cultural activities, and art exhibitions, while the upper part became the central core with a modern pedestrianized plaza. The eastern Solomon square was also restored with a new bus station (today completed) and a car park, which is currently under implementation under Omirou Avenue.

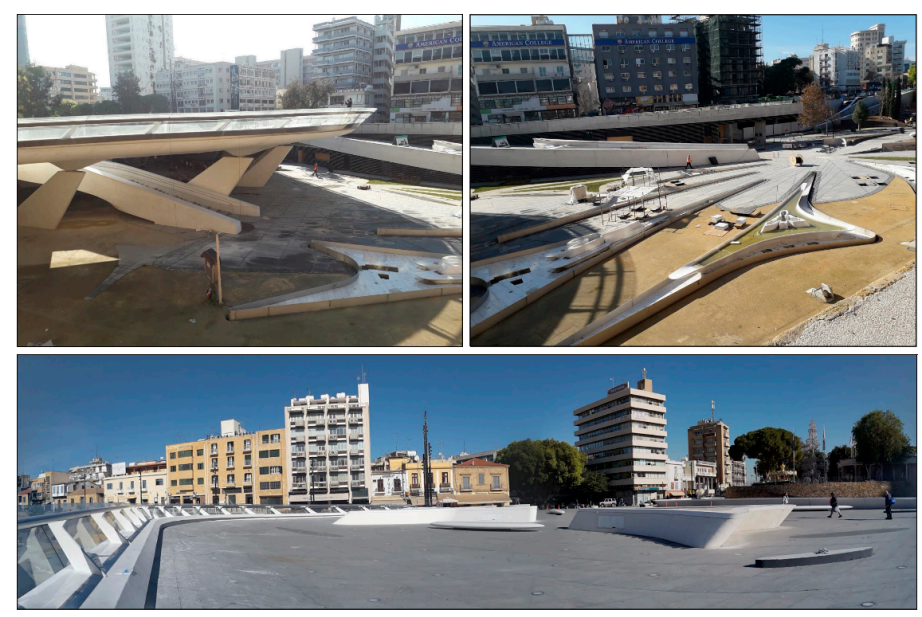

Figure 4. Eleftheria Square project: photographs of the work in progress captured in December 2019. 


\section{Methodological Approach, Data Acquisition and Processing}

As a premise to the methodological approach used, it should be noted that the project of Eleftheria Square is a long-term plan that began in 2005 with its design and, today, its implementation is still ongoing. Furthermore, during the years the geophysical support was needed for the various purposes previously introduced, which cannot be separated from a case-by-case evaluation of the methodology to be adopted. Thus, the following workflow was considered:

- Analysis of the needs of the investigation in collaboration with the technicians involved in the project, taking into consideration the typology of searched targets (archaeological remains, underground utilities, geological layers, cavities, water), their supposed depth (from centimeters to tens of meters), their constitutive material (stones, landfills, metal, plastic, fluids), their physical properties (density, conductivity, susceptibility) and their geometry (punctual targets, stretched objects, layers).

- Evaluation of the geological stratigraphy of the area. It is composed by anthropogenic soils and fluvial deposits of different thickness overlying deep marl and sandy marl of the Nicosia Formation [56].

- Evaluation of the environmental noise of the study area considering the presence of metals, buried iron grids, anthropic buried artifacts and the occurrence of recent mechanical interventions.

- Analysis of the typology of surfaces on which to operate (asphalt, concrete, paved areas, land) and the spaces available to work in.

- Consideration of the differences in the operating principles and the applicability of the various geophysical survey techniques, taking into account the previous points.

- Choice of the proper method that is suitable for solving the goal of the research. ERT, EMI and GPR were preferred over other methods. ERT, although having slower acquisition times and a small invasiveness due to the insertion of electrodes in the surfaces, was applied during surveys 1,2 and 3 in order to obtain a good compromise between depth of investigation and resolution of results, features not achievable with EMI, GPR, seismic, magnetic and gravity methods. In addition, the presence of metals, energy lines and buried grids under paved surfaces during surveys 1 and 2 excluded the use of the expeditious technique such as the magnetic method and the GPR that have an extreme sensitivity to these environmental noises. GPR was used during survey 4 and 5 with the aim to produce high-resolution maps of shallow targets such as buried pipelines. Other methods, in this urban context, would not have led to a proper representation of them. EMI prospections were applied during survey 5 as they are very suitable for the identification of high conductivity bodies in a fast way as required by the research question.

- Choice of the geophysical instruments to use during data acquisition. ERT was carried out using a multi-electrode resistivity meter, the A3000E (M.A.E. s.r.l., Frosolone, Italy). GPR was implemented through an IDS Georadar (IDS GeoRadar s.r.l., Pisa, Italy), equipped with a multi-frequency TRMF antenna (200-600 MHz), and a MALA X3M Ramac Georadar (Guideline Geo AB, Skolgatan, Sweden), equipped with a shielded $500 \mathrm{MHz}$ antenna frequency. EMI prospections were conducted utilizing the GSSI Profiler EMP-400 [57].

- Definition of the parameters of acquisition taking into consideration the required depth of investigation and the resolution required by the research question. For ERT, profiles had different lengths, taking into account the available spaces in the different survey areas and the electrode spacing was in any case set to $1.2 \mathrm{~m}$. Regarding archaeological prospections, the selected electrode spacing has been considered proper to reach supposed large deep walls. A dipole-dipole (DD) configuration was used. For GPR investigation in both cases, all radar reflections were recorded digitally in the field as 16-bit data, 512 (for IDS) and 628 (for MALA) samples per radar scan at $25 \mathrm{scan} \mathrm{s}^{-1}$ for IDS (1 scan approximately corresponds to $0.025 \mathrm{~m}$ ) and 24 scan s-1 for MALA ( 1 scan approximately corresponds to $0.024 \mathrm{~m}$ ). Half meter equally spaced GPR profiles were acquired in grids adapted to the available areas. EMI measurements were collected in stationary 
(point-to-point) mode using frequencies in the range $5-16 \mathrm{kHz}$ with vertically oriented dipoles. The investigation area was covered by profiles spaced $0.5 \mathrm{~m}$ inserted in a regular grid.

- Choice of the techniques of data processing for the selected methodologies:

- For ERT, the measured apparent resistivity datasets were processed in order to remove dragging effects that are typical of DD array and model the survey targets converting the values in real electrical resistivity values displayed as a function of depth below surface. To this end, a probability tomography approach has been applied for imaging the sources of anomalies into the analyzed grounds. The theory was first stated for the self-potential method [58], and then adapted to the resistivity method [59-61]. The primary approach, even if capable of distinguishing resistivity highs and lows in the field datasets considering a reference background resistivity, precluded the estimate of the intrinsic resistivities of the source bodies. The method was successfully used to delineate the geometry of the self-potential sources in the central volcanic area of Vesuvius (Naples, Italy) [62], to imaging through the resistivity method buried archaeological structures in the archeological site of Pompei (Naples, Italy) [63], at the Castle of Zena (Carpeneto Piacentino, Italy) [64], the prehistoric sites of Checua (Cundinamarca, Colombia) [65] and Grotta Reali (Rocchetta a Volturno, Italy) [66], the Archaeological Park of Aeclanum [67] and for fault detection in a site on the Matese Mountain (Italy) [3]. Successively, a data-adaptive probability-based ERT inversion (PERTI) method [51] was directly derived from the principles of the probability tomography in order to estimate the true resistivities. From a probabilistic point of view, the algorithm, being a non-linear approach, identifies, inside the set of possible solutions the most probable one, compatibly with the dataset acquisition scheme. The main features of the PERTI method, as reported in [51] are: (i) unnecessity of a priori information; (ii) full, unconstrained adaptability to any kind of dataset, including the case of non-flat topography; (iii) drastic reduction of computing time of even two orders of magnitude, with respect to the previous methods in complex 3D cases using the same computer; (iv) real-time inversion directly in the field, thus allowing for fast modifications of the survey plan to better focus the expected targets; (v) full independence from data acquisition techniques and spatial regularity, (vi) possibility to be used as an optimum starting model in standard iterative inversion processes in order to speed up convergence. As the PERTI method does not require a priori information and iterative processes, the computation of the route mean square (RMS) error between measured and modelled apparent resistivity values is useless. In fact, the resulting RMS error, whatever it is, can be lowered within the PERTI scheme. Many applications of the PERTI approach in near surface prospections are available in literature for solving archaeological research questions [49,68-71], for defining faults in Crete [72] and for imaging of the near-surface structure of the Solfatara crater, Campi Flegrei (Naples, Italy) [73]. In $[49,51,68,72]$ the PERTI routine was tested using well-known commercial software of inversion of geoelectrical data and the comparison put in evidence for the coherence between the obtained results and the better filter capacity and great versatility of the PERTI algorithm. Here, for the first time, the method is applied to process field datasets acquired in urban environments, as its main features fit perfectly with the needs of the case study presented.

- For GPR, as the interpretation of each section can lead to underestimation or overestimation of the reflected signals and makes it not easy to identify the effect of lateral bodies present in the subsoil, all sections were processed together using standard methodological approaches in order to obtain 2D horizontal maps at a different range of depth (GPR-SLICE 7.0 software) [74]. Data were converted by subtracting out the dc-drift (wobble) in the data, and at the same time adding a gain with time of 20. A time-zero correction was determined to designate the starting point of the wave and the center frequency of the antenna was matched. Then the bandpass filter and the background removal were respectively applied to reduce noise from oscillating 
components that had a regular frequency cycle in the frequency domain and to remove striation noises that occurred at the same time. Processed radargrams were subsequently corrected with an automatic gain function applied to each trace based on the difference between the mean amplitude of the signal in the time window and the maximum amplitude of the trace. Thus, horizontal sections (time slices) were processed considering the whole dataset. Data were gridded using the inverse distance algorithm, which includes a search of all data within a fixed radius of $0.75 \mathrm{~m}$ of the desired point to be interpolated on the grid and a smoothing factor of two. Grid cell size was set to $0.01 \mathrm{~m}$ to produce high resolution images.

- For EMI, during data elaboration the measured values of conductivity were transformed in values of resistivity and visualized in 2D maps through a contouring software.

\section{Results}

\subsection{Survey 1}

In 2008, five ERT profiles, $36 \mathrm{~m}$ long, were conducted at Eleftheria Square with the aim to cross out possible remains of ancient walls and traces of portion of D'Avila Bastion (Figure 5). It clearly appears to have an asymmetrical shape, with the uncertainty that they were destroyed during the construction of the openings in the circuit at the beginning of the 19th century. The distance between the close profiles 2-4 was $1 \mathrm{~m}$. The maximum reached depth was about $12 \mathrm{~m}$ at the center of the sections.

At $1 \mathrm{~m}$ in depth at the northeastern side of ERT 1 and ERT 5, two resistivity highs (about $300 \mathrm{Ohm}$ $\mathrm{m})$, vertically elongated, were detected (Figure $6 \mathrm{a}, \mathrm{d}$ ). They are precisely located were the portion of Venetian walls should be as pointed out with yellow dots in Figure 7a.

ERT profiles 2-5 highlight coupled medium resistive spots (about $100 \mathrm{Ohm}$ ) spaced $4 \mathrm{~m}$; the location is reported with blue circles in Figure $6 \mathrm{~b}-\mathrm{d}$. They were interpreted as the walls of the bastion. The conductive zones between them can be associated with the soil filling the fortress. In ERT 1 and ERT 5, the section of the ditch is represented by low resistivity values from the surface until a maximum depth of $8 \mathrm{~m}$. It rests on a resistive layer, the probable deep bedrock.

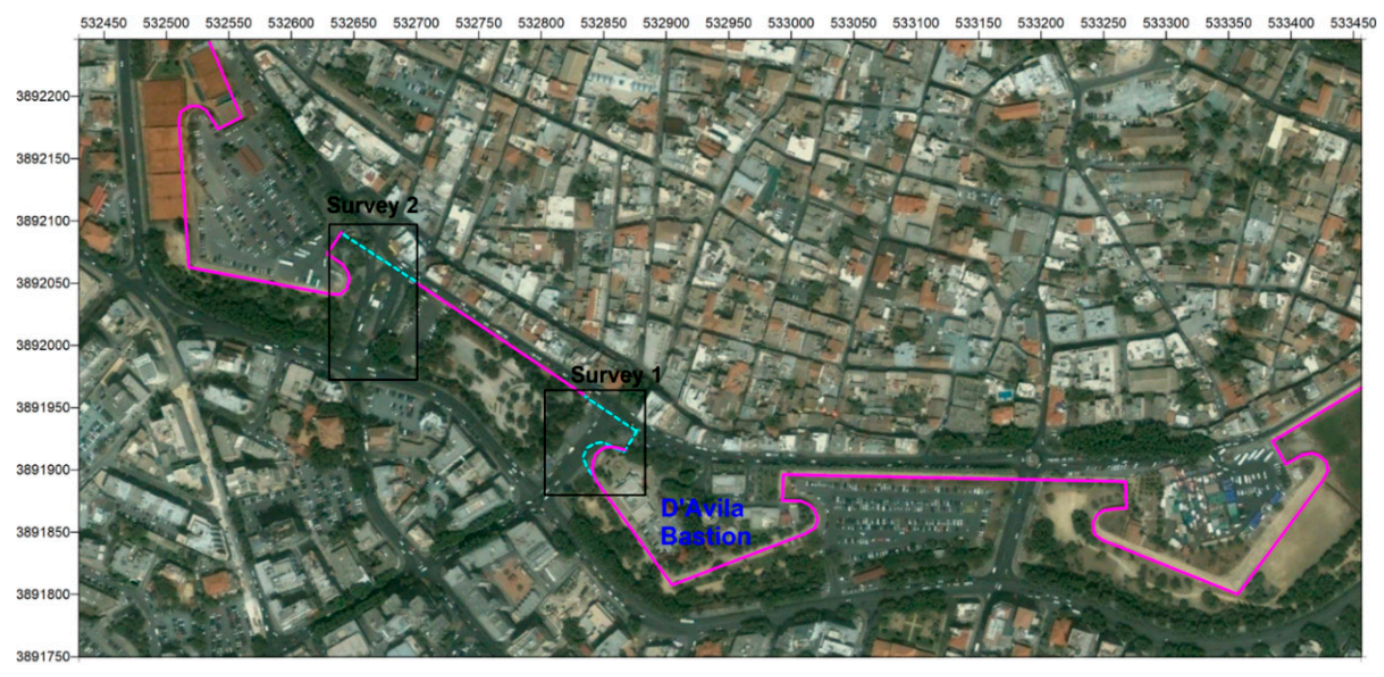

Figure 5. Google Earth ${ }^{\mathrm{TM}}$ satellite images (2008) with the indication of gaps in Venetian wall (in blue) research subjects of Surveys 1 and 2. 

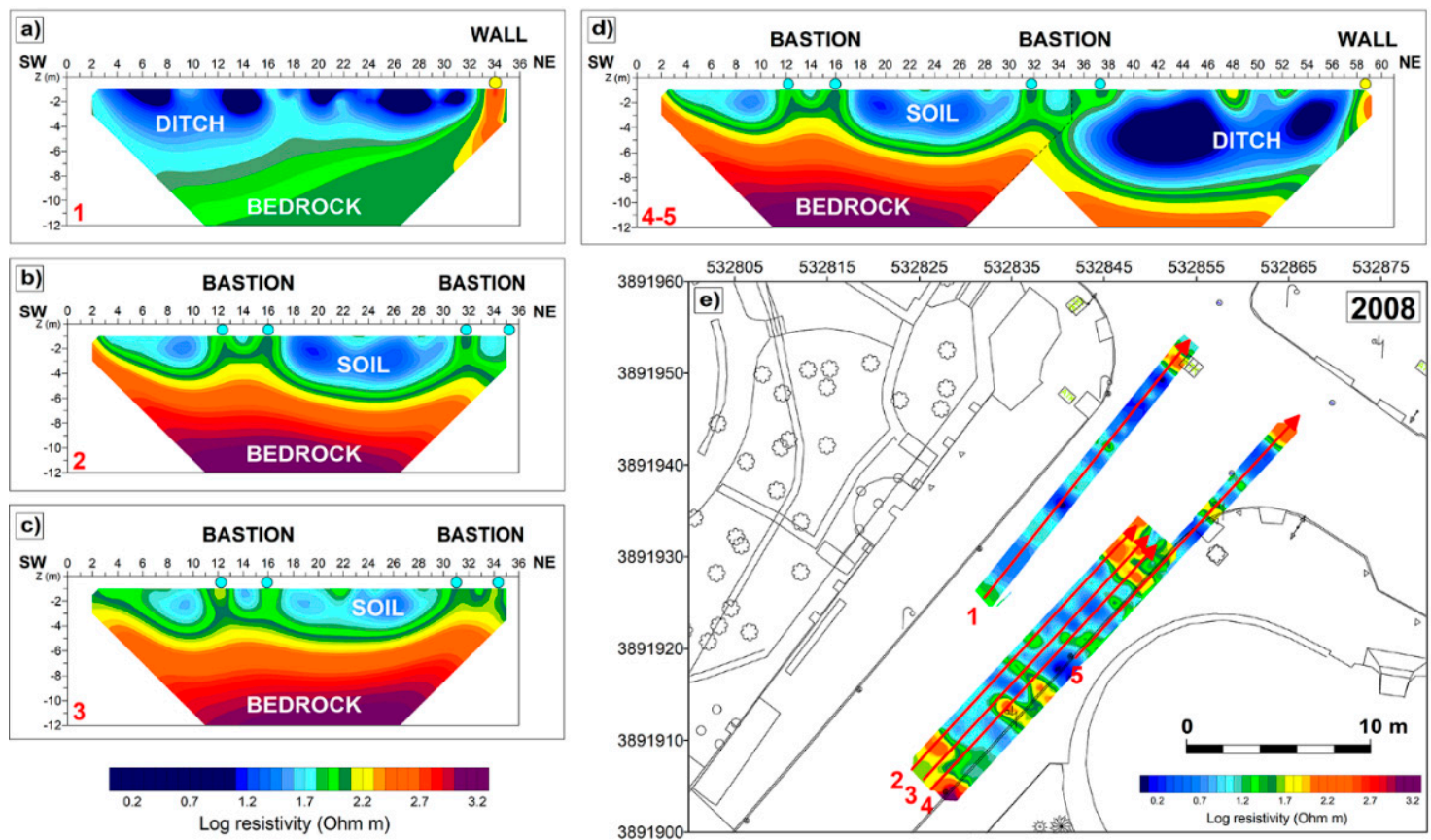

3891900

Figure 6. Eleftheria Square: ERT profiles 1-5 (a-d) and the modelled horizontal resistivity map relative to $1.2 \mathrm{~m}$ in depth (e).

Figure 6e shows a horizontal resistivity map in which the resistivity highs are located on a technical plan of the area. In order to better highlight the medium resistive spots, the limits of color scale have been slightly modified.

An archaeological excavation performed in 2009 proved the existence of the Venetian walls in the point indicated at the end of ERT 5 and the bastion was entirely brought to light in the exact points indicated by geophysical prospections (Figures 6 and 7a). The ditch was also partially excavated. Subsequently, the original project of the new square needed to be modified, maintaining a distance of $3 \mathrm{~m}$ between the new construction and the northwestern side of the bastion as regulated by the International Charter for the Conservation of Monuments and Sites. The new construction is now completed, and it incorporates the ancient bastion (Figure $7 \mathrm{~b}$ ).
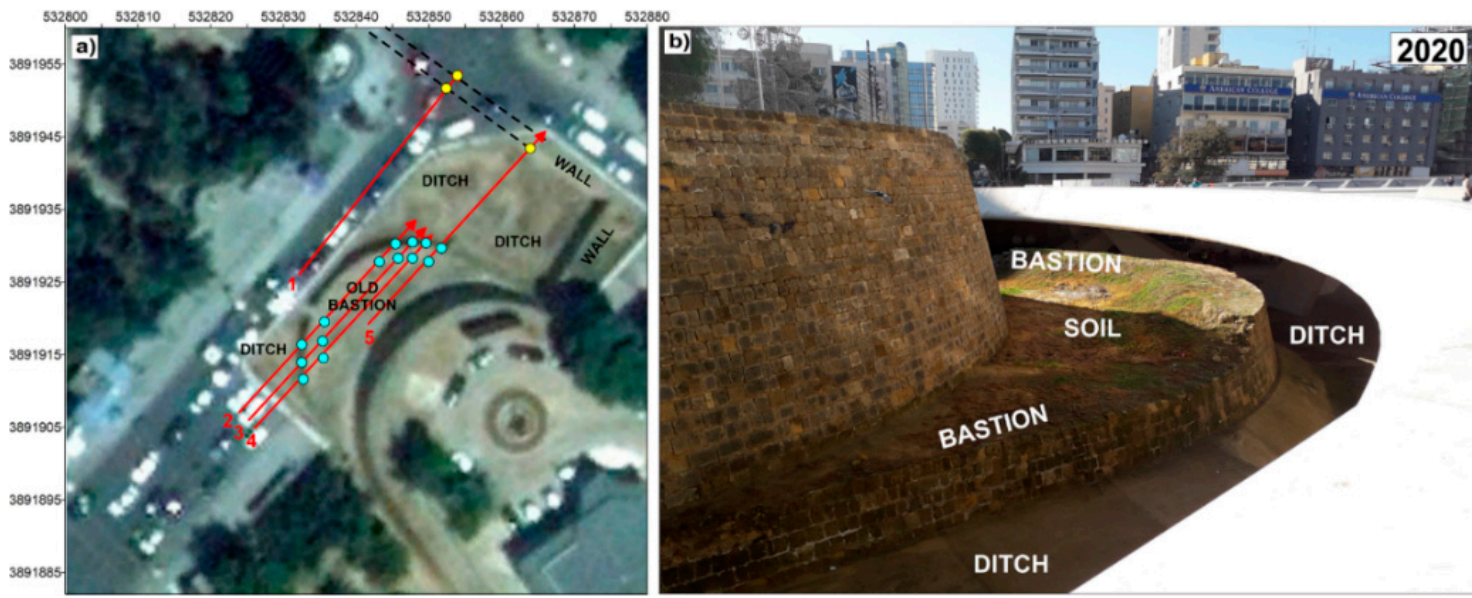

Figure 7. Eleftheria Square: Location of ERT profiles 1-5 and geophysical anomalies on a Google Earth $^{\mathrm{TM}}$ satellite images (2011) after archaeological excavations at Eleftheria Square (a) and a picture of the excavated ancient bastion inserted in the new square (b). 


\subsection{Survey 2}

Survey 2 was carried in 2008 and concerned Solomos Square, where the city's bus station is, at the intersection of Rigenis Street and Omirou Avenue (Figures 2 and 8a). Here, the presence of buried walls and archaeological remains were the target of the investigation. Five ERT profiles (6-10) with different lengths where acquired. ERT profiles 7-9 (Figure 8d-f), located at the center of the square, clearly put forth evidence of the filling of the ditch and the deep resistive substratum. With the exception of rare near-surface high-resistivity nuclei probably due to modern alteration, the unique dishomogeneities that can be attributable to ancient walls are the high-resistive features located at the right side of ERT profiles 6 and 10 (yellow dots in Figure 8a,c,f). In 2010, the square was remodeled, and direct archaeological excavations were not performed to verify geophysical results.

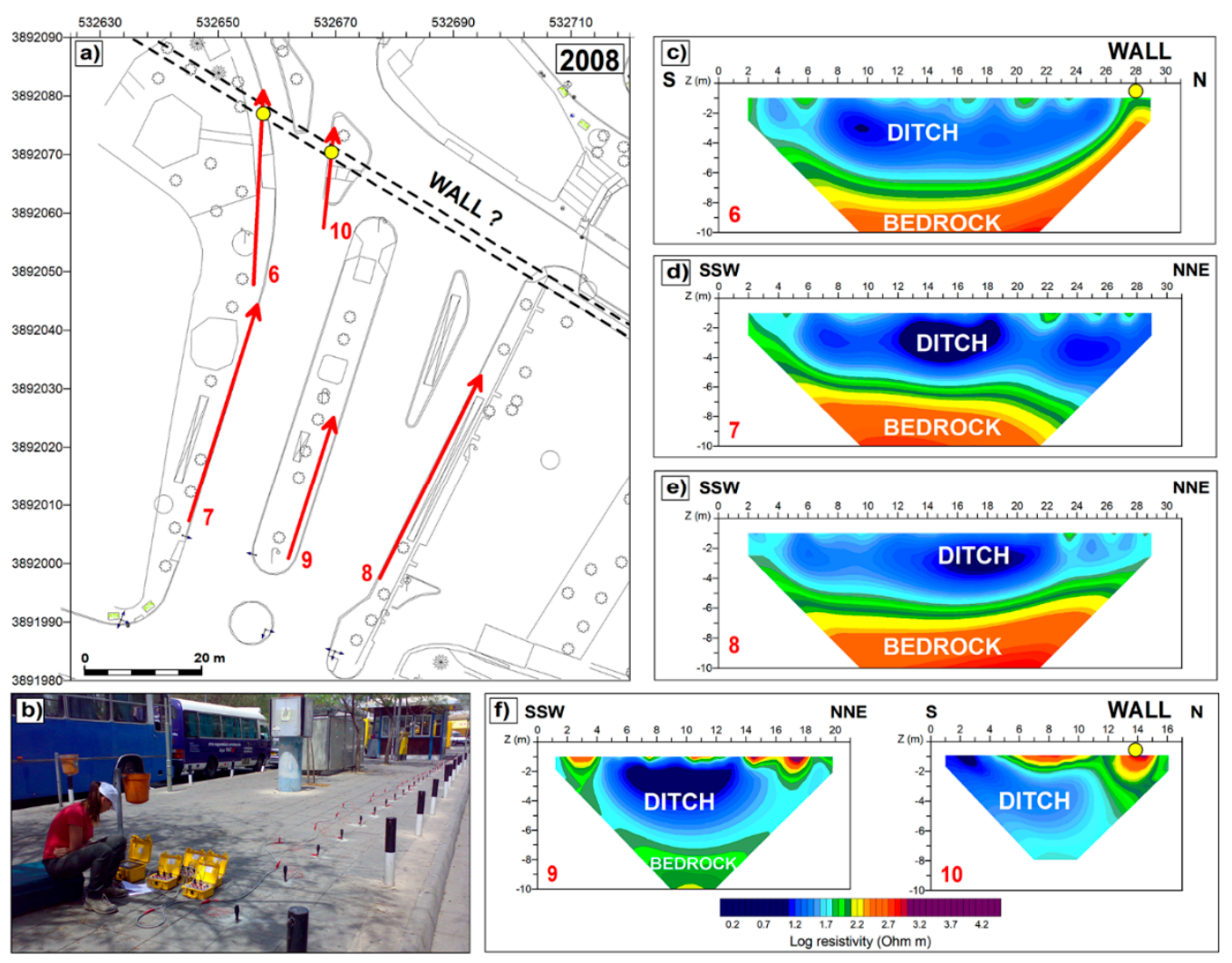

Figure 8. Solomon Square: location of ERT profiles 6-10 (a), data acquisition (b) and geophysical results $(\mathbf{c}-\mathbf{f})$.

\subsection{Surveys $3-4$}

In 2009, twelve ERT profiles were carried out along Omirou Avenue with the aim of imaging the stratigraphy of the soil and to verify the presence of archaeological structures into the subsoil (ERT profiles 11-22 in Figure 9). As the planning of the survey was influenced by the necessity to ensure the traffic of cars, two main fragmented lines of investigation were conducted (blue and red lines in Figure 9). Profiles had variable lengths and the depth reached for all was $10 \mathrm{~m}$. Figure 10 shows two tridimensional perspective views of the imaged ERT profiles. In general, a uniform stratigraphy is detected and characterized by materials with low resistivity values. In some cases, an increase of resistivity can be attested at about $8 \mathrm{~m}$ in depth. High resistivity features that can be associated to huge empty cavities were not detected, as well as it was not possible to distinguish small cavities filled up with loose conductive sediments. 


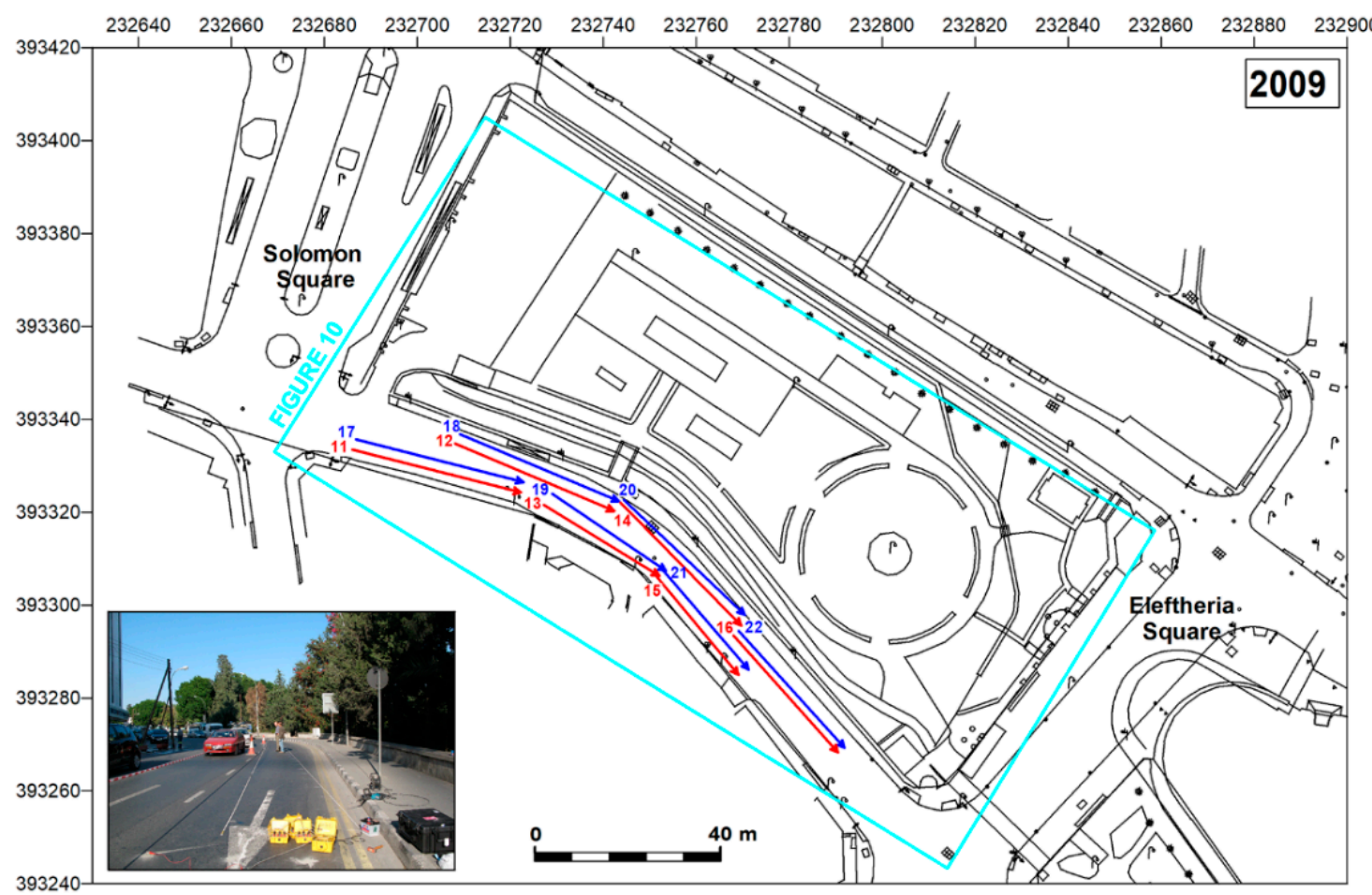

Figure 9. Omirou Avenue: location of ERT profiles 11-22. Blue and red lines indicate the two main fragmented lines of investigation.
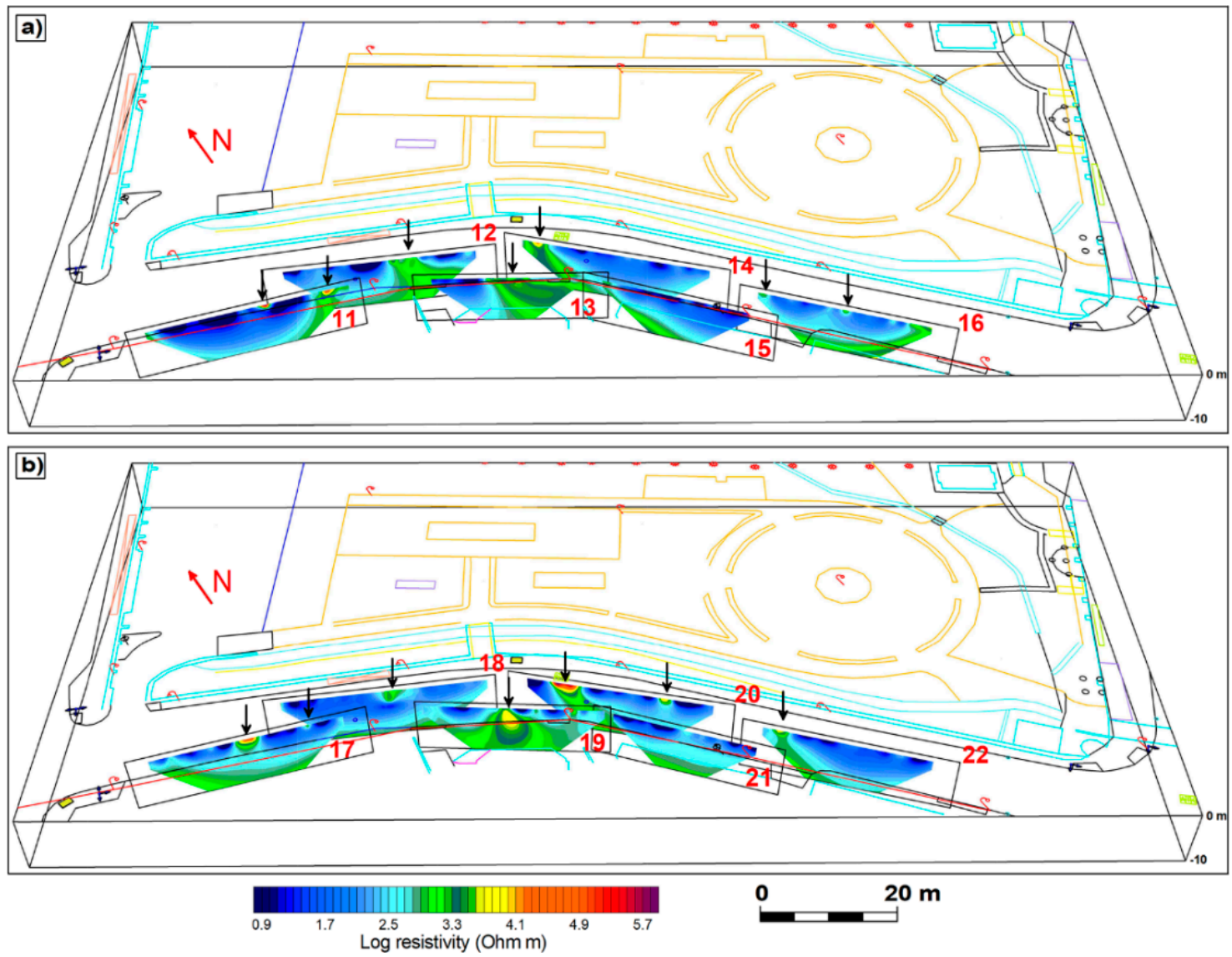

Figure 10. Omirou Avenue: 3D perspective views of ERT profiles 11-16 (a) and 17-22 (b). 
Resistivity features with well-defined shapes similar to the ones that were detected on the ERT profiles of surveys 1 and 2 are not attested here, such as to hypothesize the presence of archaeological remains under the road plane. However, isolated shallow high resistivity values were highlighted in each section (marked with black arrows in Figure 10) that can suggest the existence of nuclei with a non-vanishing probability to find ancient remains. Noteworthy are the two high resistive nuclei that repeat on the ERT profiles 13,14, 19 and 20, which seem to be on the same route.

In 2017, before the removal of the asphalt layer from the road, a GPR survey was performed. Figure 11a displays two examples of radargrams in which punctual targets, probable manholes, and horizontal discontinuities are marked with coloured arrows. The same marks are reported on the horizontal slice relative to the time window 10-15 ns, the one that better enhances the presence of targets into the subsoil (Figure 11b). The map shows the presence of different linear high amplitude values of the electromagnetic signal that probably refer to pipes buried into the shallow ground. Particularly evident is the presence of a high amplitude feature flanking the south side of the road attributable to the underground sewer pipes (with dotted lines in Figure 11b). Furthermore, the map clearly highlights the presence of manholes indicated with crosses in Figure 11b.
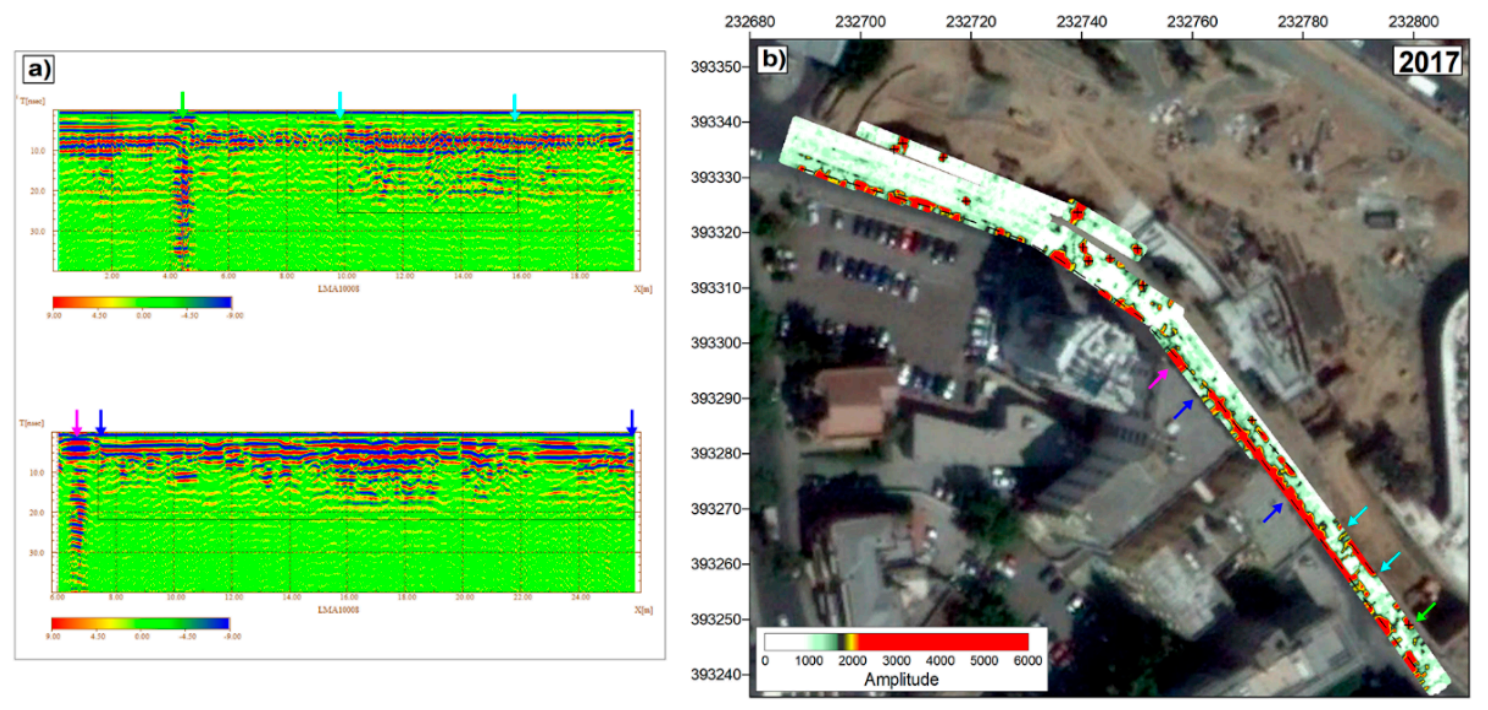

Figure 11. Omirou Avenue: two examples of radargrams (a) and GPR slice relative to the time window 10-15 ns. (b) Dotted lines and crosses indicate respectively underground pipes and manholes; the colored arrows mark the same anomalies on radargrams and slice.

\subsection{Survey 5}

In 2019, an unexpected problem occurred during the works: inside the underground substation where electrical cables arranged in six plastic pipes converge, water began to flow in a very abundant cascade directly from the pipes. To try to find out the cause, an excavation trench was carried out south of the cabin (Figure 12a), partially bringing to light the cables that were embedded inside a layer of reinforced concrete. The action was not conclusive as the leak could not be detected. The most reliable hypothesis of the origin of the water was the breakdown of the sewage pipes detected by the GPR in 2017 that pass to the center of the road junction, but no evidence was identified by direct verification. To this point, GPR and EMI investigations were performed in the very few spaces available (Figure 12b).

The resistivity maps obtained from the EMI survey allowed for locating the most probable wet areas. Figure 13 shows all the horizontal maps relating to the frequencies from $16 \mathrm{kHz}$ to $5 \mathrm{kHz}$. At the edge of the sidewalk there is a conductive band that at lower frequencies (which give us information at greater depths) gradually flags and highlights the retaining wall of the underground rooms in the square. The slice that showed the highest conductivity is that related to the $11 \mathrm{kHz}$ frequency 
(Figure 14b). The maps relative to lower frequencies put in evidence of a decreasing of the conductive values and highlight the resistive piles of reinforcement.
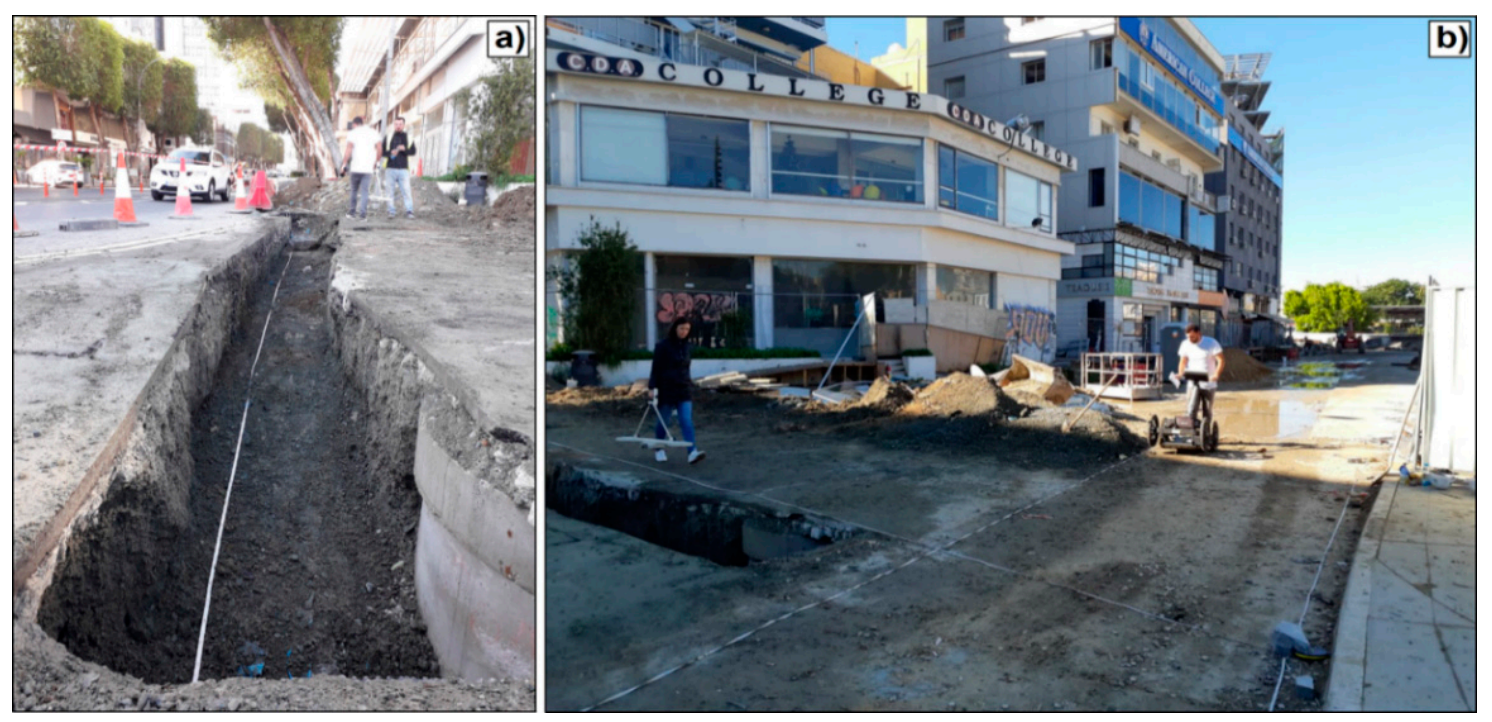

Figure 12. Corner between Evagorou Avenue and Omirou Avenue: the excavated trench (a), GPR and EMI data acquisition (b).

As expected, the GPR survey was not a solution in wet areas because the water completely absorbed the electromagnetic signal (Figure 14a). However, the buried electric cabin was precisely reported on the map and two nuclei with high amplitude of the electromagnetic signals, possible manholes, were detected.

A targeted excavation verification at that point confirmed the presence of conspicuous water into the soil. Although the origin of the water has not been identified, the investigation has averted the southern origin of the leak as hypothesized before the investigation. The most probable theory is that the problem should originate to the west of the trench where the pipeline of the city aqueduct is located. The issue is still being analyzed through inexpensive and non-invasive solutions. 


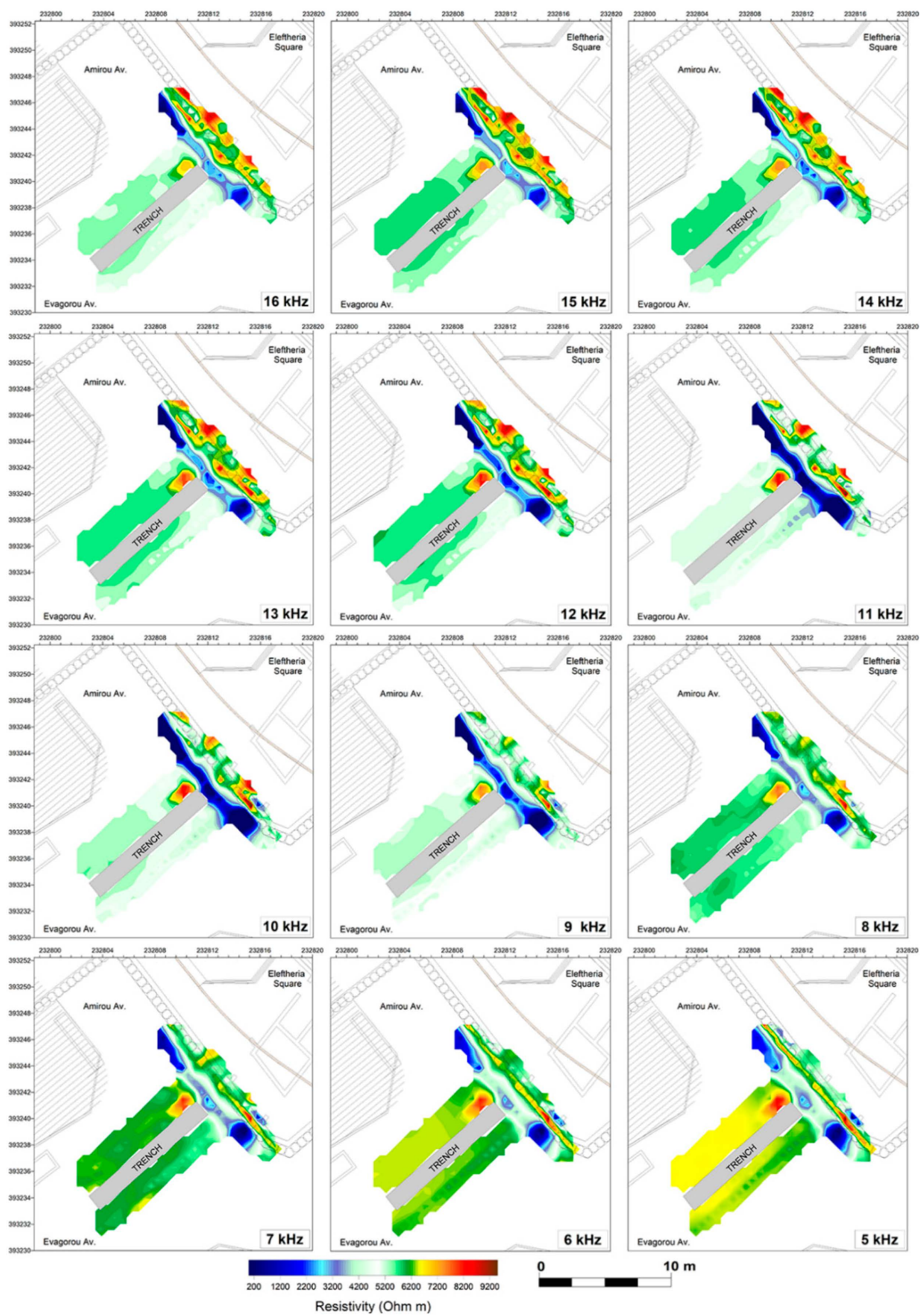

Figure 13. EMI resistivity maps relative to the frequencies in the range $16-5 \mathrm{kHz}$. 


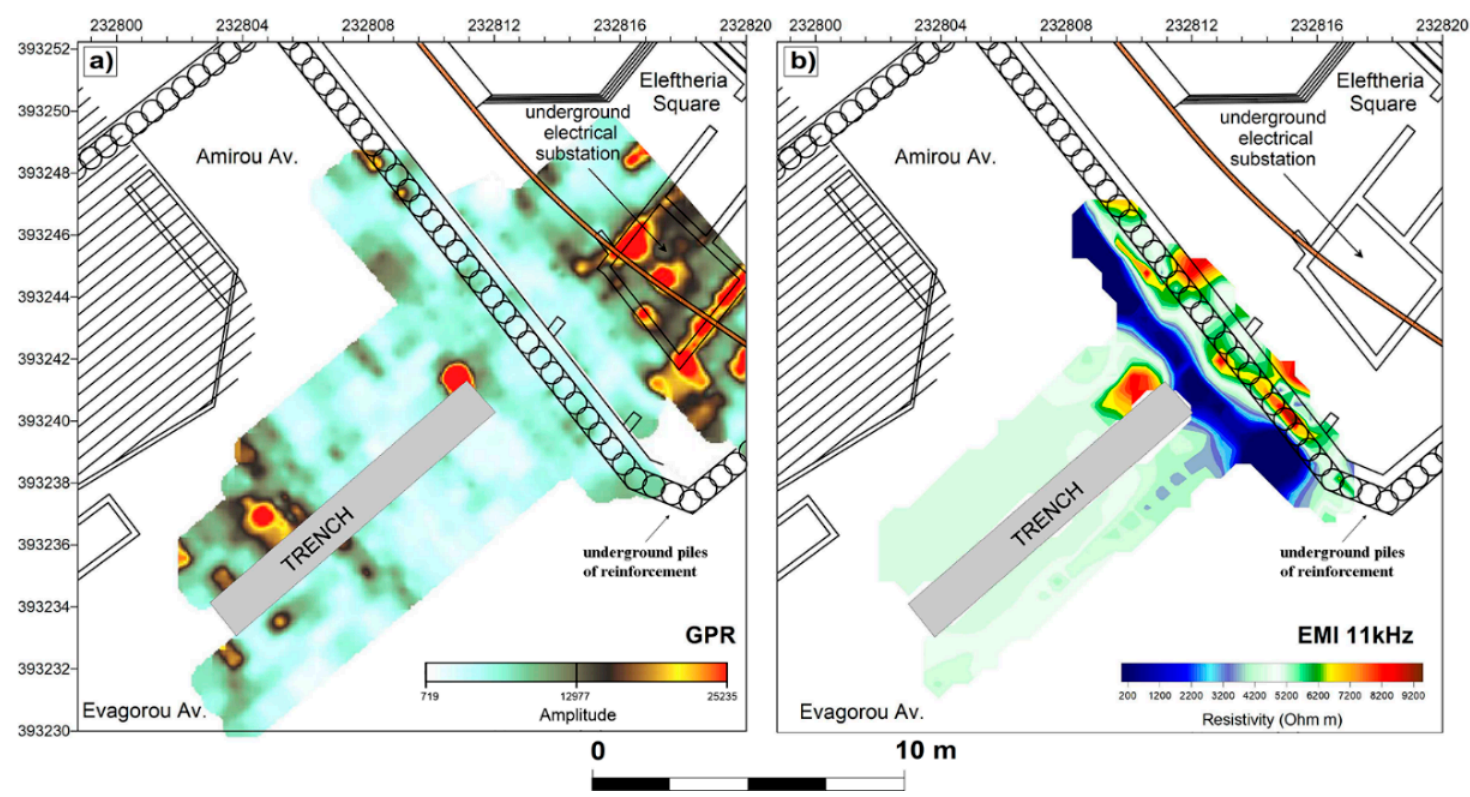

Figure 14. GPR slice relative to the time window 14-18 ns (a), EMI resistivity map relative to the frequency of $11 \mathrm{kHz}(\mathbf{b})$.

\section{Conclusions}

This paper concerned the contribution of non-destructive investigations within the redesigning project of Eleftheria Square and its cultural value protection according to its important role in the life of the city of Nicosia.

As a premise which forms an integral part of the discussion of the reported results, it is important to emphasize that the unique limitation of the methodological approach used in this work is in the general principle of geophysical diagnostics as it is an indirect methodology aimed at the spatial definition of anomalies present in the subsoil. Only a direct verification in the field can give certainty of the nature of the buried objects and in the case of ancient finds can define their age and the real archaeological value of the anomalies found. On the contrary, the strength of preventive investigations is the non-invasiveness of the survey, the speed of data acquisition and the possibility of being able guide direct investigations in a targeted and precise manner.

The Elephteria Square redesign project is an important case study for its majesty and prestige and for the historical and cultural context within which it is inserted. The activities lasted more than ten years, from 2008 until today, and the geophysical researches were an integral part of the project. Geophysical research combined with this type of initiative is important as it can be easily replicated in one of the many historical centers scattered around Cyprus or in other parts of the world interested in changes in new urban planning that can have an impact on modern and ancient structures.

The obtained results provided a precise answer to the research questions. In particular, the evaluation of the potential archaeological risk at Eleftheria Square and Solomon Square in 2008 , before the beginning of the construction of the new structure, was successfully reached through the application of ERTs: the highs of resistivity interpreted as buried archaeological constructions were proved to be, after excavation, part of the Venetian wall and portions of D'Avila Bastion. Such a result allowed for preserving pieces of the local culture, avoiding its destruction. Furthermore, once discovered, they were inserted within the new complex of the square, adopting a modification to the project in order to highlight the archaeological findings.

The ERT surveys along Amirou Avenue in 2009 have permitted to delineate the geological stratigraphy of the soils, clarifying the absence of huge empty cavities and suggesting the existence of near surface resistive nuclei that probably can be attributable to ancient remains. 
Regarding the methodological approach used to process electrical resistivity datasets, the data-adaptive probability-based ERT inversion (PERTI) method was proven to be appropriate for urban measurements because of its ability to remove dragging effects due to the dipole-dipole configuration used and to filter, sometimes, very noisy raw data. In general, within the first application of the probability tomography in urban settings, a good performance in drawing sections is proved.

The GPR surveys, using standard technique of data acquisition and processing, along Amirou Avenue in 2017 allowed the precise detection of underground utilities facilitating the technicians during works of excavation and avoiding unexpected damages to city supplies.

Finally, GPR and EMI investigations were carried out in order to understand the reason for an abundant flow of water that occurred inside the new underground electrical substation positioned under the new Eleftheria Square during excavations at the intersection of Evagorou Avenue and Omirou Avenue in 2009. As expected, the GPR survey was not able to overcome the limit of the presence of water but it was useful to report the precise location of the buried electric cabin on the map. The resistivity maps obtained from the EMI survey allowed the precise locating of the most probable wet areas. A targeted excavation verification at that point confirmed the presence of conspicuous water into the soil, averting the southern origin of the leak as hypothesized before the investigation.

In general, the geophysical results proved the efficiency of the adopted methods, adding scientific value to the status of knowledge of the subject area of study. In some cases, the verification of the supposed buried features was proved by excavation and a perfect correspondence between the geophysical previsions and the structures found in the subsoil was attested. In addition, the presented research supported the actions of the technicians involved in each phase of the project and often, in emergency, the results were provided in real time to resolve the problems encountered. A result of all the various urban activities is, in fact, the collaboration between geophysicists and urban decision makers, which should be encouraged in cases similar to that presented for an optimal city management.

Author Contributions: Conceptualization, M.C. and P.M.; methodology, M.C. and P.M.; software, M.C. and P.M.; validation, M.C. and P.M.; formal analysis, M.C. and P.M.; investigation, M.C., V.G. and P.M.; data curation, M.C., V.G. and P.M.; writing-original draft preparation, M.C., P.M. and A.P.; writing-review and editing, M.C. and P.M.; supervision, P.M. and A.P.; project administration, P.M. and A.P.; funding acquisition, P.M. and A.P. All authors have read and agreed to the published version of the manuscript.

Funding: This research received no external funding.

Acknowledgments: The Ministry of Foreign Affairs of Italy, in the frame of the Archaeological Missions, and Nicosia Master Plan funded part of this research. We thank the Embassy of Italy and the Ambassador Andrea Cavallari for the continuous support for the activities and His Excellency Gherardo La Francesca for being the promoters of this Italian-Cypriot collaboration. Special thanks to the technicians of Nicosia Municipality for administrative and technical support during the research activities.

Conflicts of Interest: The authors declare no conflict of interest.

\section{References}

1. Nguyen, F.; Garambois, S.; Chardon, D.; Hermitte, D.; Bellier, O.; Jongmans, D. Subsurface electrical imaging of anisotropic formations affected by a slow active reverse fault, Provence, France. J. Appl. Geophys. 2007, 62, 338-353. [CrossRef]

2. Moisidi, M.; Vallianatos, F.; Soupios, P.; Kershaw, S. Spatial spectral variations of microtremors and electrical resistivity tomography surveys for fault determination in southwestern Crete, Greece. J. Geophys. Eng. 2012, 9, 261-270. [CrossRef]

3. Valente, E.; Ascione, A.; Ciotoli, G.; Cozzolino, M.; Porfido, S.; Sciarra, A. Do moderate magnitude earthquakes generate seismically induced ground effects? The case study of the Mw = 5.16, 29th December 2013 Matese earthquake (southern Apennines, Italy). Int. J. Earth Sci. 2013, 107, 517-537. [CrossRef]

4. Bichler, A.; Bobrowsky, P.; Best, M.; Douma, M.; Hunter, J.; Calvert, T.; Burns, R. Three-dimensional mapping of a landslide using a multi-geophysical approach: The Quesnel Forks landslide. Landslides 2004, 1, $29-40$. [CrossRef] 
5. Jäger, D.; Sandmeier, C.; Schwindt, D.; Terhorst, B. Geomorphological and geophysical analyses in a landslide area near Ebermannstadt, Northern Bavaria. E G Quat. Sci. J. 2013, 62, 150-161. [CrossRef]

6. Grippa, A.; Bianca, M.; Tropeano, M.; Cilumbriello, A.; Mucciarelli, M.; Sabato, L.; Scalo, T. Use of the HVSR method to detect buried paleomorphologies (filled incised-valleys) below a coastal plain: The case of the metaponto plain (Basilicata, Southern Italy). Boll. Geofis. Teor. Appl. 2011, 52, 225-240.

7. Green, R.T.; Klar, R.V.; Prikryl, J.D. Use of Integrated Geophysics to Characterize Paleo-Fluvial Deposits. In Proceedings of the Site Characterization and Modeling, Geo-Frontiers Congress, Austin, TX, USA, 24-26 January 2015; American Society of Civil Engineers: Reston, VA, USA, 2015; pp. 1-13.

8. Davis, J.L.; Annan, A.P. Ground-penetrating radar for high-resolution mapping of soil and rock stratigraphy 1. Geophys. Prospect. 1989, 37, 531-551. [CrossRef]

9. Darwin, R.L.; Ferring, C.R.; Ellwood, B.B. Geoelectric stratigraphy and subsurface evaluation of quaternary stream sediments at the Cooper Basin, NE Texas. Geoarchaeology 1990, 5, 53-79. [CrossRef]

10. Martel, R.; Castellazzi, P.; Gloaguen, E.; Trépanier, L.; Garfias, J. ERT, GPR, InSAR, and tracer tests to characterize karst aquifer systems under urban areas: The case of Quebec City. Geomorphology 2018, 310, 45-56. [CrossRef]

11. Zini, L.; Calligaris, C.; Forte, E.; Petronio, L.; Zavagno, E.; Boccali, C.; Cucchi, F. A multidisciplinary approach in sinkhole analysis: The Quinis village case study (NE-Italy). Eng. Geol. 2015, 197, 132-144. [CrossRef]

12. Kaufmann, G.; Romanov, D.; Tippelt, T.; Vienken, T.; Werban, U.; Dietrich, P.; Mai, F.; Börner, F. Mapping and modelling of collapse sinkholes in soluble rock: The Münsterdorf site, northern Germany. J. Appl. Geophys. 2018, 154, 64-80. [CrossRef]

13. Titov, K.; Loukhmanov, V.; Potapov, A. Monitoring of water seepage from a reservoir using resistivity and self polarization methods: Case history of the Petergoph fountain water supply system. First Break 2000, 18, 431-435. [CrossRef]

14. Nabighian, M.N.; Grauch, V.J.S.; Hansen, R.O.; LaFehr, T.R.; Li, Y.; Peirce, J.W.; Phillips, J.D.; Ruder, M.E. The historical development of the magnetic method in exploration. Geophysics 2005, 70, 33ND-61ND. [CrossRef]

15. Gavazzi, B.; Bertrand, L.; Munschy, M.; de Lépinay, J.M.; Diraison, M.; Géraud, Y. On the Use of Aeromagnetism for Geological Interpretation: 1. Comparison of Scalar and Vector Magnetometers for Aeromagnetic Surveys and an Equivalent Source Interpolator for Combining, Gridding, and Transforming Fixed Altitude and Draping Data Sets. J. Geophys. Res. Solid Earth 2020, 125, 018870. [CrossRef]

16. Bertrand, L.; Gavazzi, B.; de Lépinay, J.M.; Diraison, M.; Géraud, Y.; Munschy, M. On the Use of Aeromagnetism for Geological Interpretation: 2. A Case Study on Structural and Lithological Features in the Northern Vosges. J. Geophys. Res. Solid Earth 2020, 125, 017688. [CrossRef]

17. Gavazzi, B.; le Maire, P.; de Lépinay, J.M.; Calou, P.; Munschy, M. Fluxgate three-component magnetometers for cost-effective ground, UAV and airborne magnetic surveys for industrial and academic geoscience applications and comparison with current industrial standards through case studies. Geomech. Energy Environ. 2019, 20, 100117. [CrossRef]

18. Nabighian, M.N.; Ander, M.E.; Grauch, V.J.S.; Hansen, R.O.; la Fehr, T.R.; Li, Y.; Ruder, M.E. Historical development of the gravity method in exploration Historical Development of Gravity Method. Geophysics 2005, 70, 63ND-89ND. [CrossRef]

19. Scollar, I. Electromagnetic Prospecting Methods in Archaeology. Archaeometry 1962, 5, 146-153. [CrossRef]

20. Bozzo, E.; Merlanti, F.; Ranieri, G.; Sambuelli, L.; Finzi, E. EM-VLF soundings on the eastern hill of the archaeological site of Selinunte. Boll. Geofis. Teor. Appl. 1991, 34, 132-140.

21. Fassbinder, J.W.E.; Reindel, M. Magnetometer prospection as research for pre-Spanish cultures at Nasca and Palpa, Perù. In Proceedings of the 6th International Archaeological Prospection Conference, CNR, Rome, Italy, 14-17 September 2005; Piro, S., Ed.; Institute of Technologies Applied to Cultural Heritage: Rome, Italy, 2005; pp. 6-10.

22. Mol, L.; Preston, P.R. The writing's in the wall: A review of new preliminary applications of electrical resistivity tomography within archaeology. Archaeometry 2010, 52, 1079-1095. [CrossRef]

23. Tsokas, G.N.; Tsourlos, P.I.; Kim, J.-H.; Yi, M.-J.; Vargemezis, G.; Lefantzis, M.; Fikos, E.; Peristeri, K. ERT imaging of the interior of the huge tumulus of Kastas in Amphipolis (northern Greece). Archaeol. Prospect. 2018, 25, 347-361. [CrossRef] 
24. Urban, T.M.; Leon, J.F.; Manning, S.W.; Fisher, K.D. High resolution GPR mapping of Late Bronze Age architecture at Kalavasos-Ayios Dhimitrios, Cyprus. J. Appl. Geophys. 2014, 107, 129-136. [CrossRef]

25. Cozzolino, M.; Gentile, V.; Giordano, C.; Mauriello, P. Imaging Buried Archaeological Features through Ground Penetrating Radar: The Case of the Ancient Saepinum (Campobasso, Italy). Geosciences 2020, 10, 225. [CrossRef]

26. Knudson, D.L.; Rempe, J. Linear variable differential transformer (LVDT)-based elongation measurements in Advanced Test Reactor high temperature irradiation testing. Meas. Sci. Technol. 2012, 23, 025604. [CrossRef]

27. Burrows, S.E.; Rashed, A.; Almond, D.P.; Dixon, S. Combined laser spot imaging thermography and ultrasonic measurements for crack detection. Nondestruct. Test. Eval. 2007, 22, 217-227. [CrossRef]

28. Candoré, J.C.; Bodnar, J.-L.; Detalle, V.; Grossel, P. Non destructive testing in situ, of works of art by stimulated infra-red thermography. J. Phys. Conf. Ser. 2010, 214, 012068. [CrossRef]

29. Costanzo, A.; Minasi, M.; Casula, G.; Musacchio, M.; Buongiorno, M.F. Combined Use of Terrestrial Laser Scanning and IR Thermography Applied to a Historical Building. Sensors 2014, 15, 194-213. [CrossRef]

30. Arias, P.; Armesto, J.; di Capua, D.; Gonzalez-Drigo, R.; Lorenzo, H.; Perez-Gracia, V. Digital photogrammetry, GPR and computational analysis of structural damages in a mediaeval bridge. Eng. Fail. Anal. 2007, 14, 1444-1457. [CrossRef]

31. Cozzolino, M.; Gabrielli, R.; Galata', P.; Gentile, V.; Greco, G.; Scopinaro, E. Combined use of 3D metric surveys and non-invasive geophysical surveys for the determination of the state of conservation of the Stylite Tower (Umm ar-Rasas, Jordan). Ann. Geophys. 2019, 61, 72. [CrossRef]

32. Cozzolino, M.; di Meo, A.; Gentile, V. The contribution of indirect topographic surveys (photogrammetry and laser scanner) and GPR investigations in the study of the vulnerability of the Abbey of Santa Maria a Mare, Tremiti Islands (Italy). Ann. Geophys. 2019, 61, 71. [CrossRef]

33. Available online: https://seg.org/Events/Distributed-Sensing-for-Geophysics (accessed on 25 May 2020).

34. Available online: https://www.eage.org/event/?eventid=1419\&evp=18807 (accessed on 25 May 2020).

35. Available online: https://www.eegs.org/sageep-2018-special-session--geophysics-for-urban-undergroundspace-development-i (accessed on 25 May 2020).

36. Available online: https://www.science-community.org/en/node/177491 (accessed on 25 May 2020).

37. Available online: https://www.sciencedirect.com/journal/engineering-geology/special-issue/10WK1QM13L7 (accessed on 25 May 2020).

38. Available online: https://www.mdpi.com/journal/geosciences/special_issues/urban_geophysics (accessed on 25 May 2020).

39. Miller, R. Introduction to this special section: Urban geophysics. Geophysics 2013, 32, 248-249. [CrossRef]

40. Piscitelli, S.; Rizzo, E.; Cristallo, F.; Lapenna, V.; Crocco, L.; Persico, R.; Soldovieri, F. GPR and microwave tomography for detecting shallow cavities in the historical area of "Sassi of Matera" (southern Italy). Near Surf. Geophys. 2007, 5, 275-284. [CrossRef]

41. Gabàs, A.; Macau, A.; Benjumea, B.; Bellmunt, F.; Figueras, S.; Vila, M. Combination of Geophysical Methods to Support Urban Geological Mapping. Surv. Geophys. 2013, 35, 983-1002. [CrossRef]

42. Rizzo, E.; Capozzoli, L.; de Martino, G.; Grimaldi, S. Urban geophysical approach to characterize the subsoil of the main square in San Benedetto del Tronto town (Italy). Eng. Geol. 2019, 257, 105133. [CrossRef]

43. Lück, E.; Eisenreich, M.; Spangenberg, U.; Christl, G. A note on geophysical prospection of archaeological structures in urban contexts in Potsdam (Germany). Archaeol. Prospect. 1997, 4, 231-238. [CrossRef]

44. Amato, V.; Cozzolino, M.; de Benedittis, G.; di Paola, G.; Gentile, V.; Giordano, C.; Marino, P.; Rosskpof, C.M.; Valente, E. An integrated quantitative approach to assess the archaeological heritage in highly anthropized areas: The case study of Aesernia (southern Italy). Acta IMEKO 2016, 5, 33. [CrossRef]

45. Paz-Arellano, P.; Tejero-Andrade, A.; Argote-Espino, D. 2D-ERT Survey for the Identification of Archaeological and Historical Structures beneath the Plaza of Santo Domingo, Mexico City, Mexico. Archaeol. Prospect. 2016, 24, 183-194. [CrossRef]

46. Sagnard, F.; Norgeot, C.; Dérobert, X.; Baltazart, V.; Merliot, E.; Derkx, F.; Lebental, B. Utility detection and positioning on the urban site Sense-City using Ground-Penetrating Radar systems. Measurement 2016, 88, 318-330. [CrossRef]

47. Sărăcin, A. Using georadar systems for mapping underground utility networks. Procedia Eng. 2017, 209, 216-223. [CrossRef] 
48. Camocio, G.F.; Bertelli, D.; Zenoi, D.; Rota, M.; Furlani, P. Isole Famose Porti, Fortezze, e Terre Maritime Sottoposte Alla Ser.ma Sig.ria di Venetia, ad Altri Principi Christiani, et al. Sig.or Turco, Nouame[n]te Poste in Luce; Alla libraria del segno di S. Marco: Venice, Italy, 1570-1573; pp. 97-100.

49. Cozzolino, M.; Mauriello, P.; Patella, D. Resistivity Tomography Imaging of the Substratum of the Bedestan Monumental Complex at Nicosia, Cyprus. Archaeometry 2013, 56, 331-350. [CrossRef]

50. Cozzolino, M.; di Giovanni, E.; Mauriello, P. Geophysical prospections applied to historical centres. In Proceedings of the 19th International Conference on Cultural Heritage and New Technologies 2014 (CHNT 19, 2014), Vienna, Austria, 3-5 November 2014; pp. 1-14.

51. Mauriello, P.; Patella, D. A data-adaptive probability-based fast ERT inversion method. Prog. Electromagn. Res. 2009, 97, 275-290. [CrossRef]

52. Oktay, D. An Analysis and Review of the Divided City of Nicosia, Cyprus, and New Perspectives. Geography 2007, 3, 234-236.

53. Petridou, A. Nicosia Master Plan: Perspectives for Urban Rehabilitation-Building Bridges between the Two Communities of the Divided City of Nicosia; EU Partnership for the Future Programme; Nicosia Municipality: Nicosia, Cyprus, 2010.

54. Petridou, A. Rehabilitating Traditional Mediterranean Architecture. The Nicosia Rehabilitation Project: An Integrated Plan; Monumenta, Nicosia Municipality: Nicosia, Cyprus, 2007.

55. Available online: www.zaha-hadid.com/masterplans/eleftheria-square (accessed on 24 April 2020).

56. Harrison, R.W.; Newell, W.L.; Panayides, I.; Stone, B.; Tsiolakis, E.; Necdet, M.; Batihanli, H.; Ozhur, A.; Lord, A.; Berksoy, O.; et al. Bedrock Geologic Map of the Greater Lefkosia Area, Cyprus; US Geological Survey: Reston, VA, USA, 2008.

57. Available online: www.geophysical.com (accessed on 24 April 2020).

58. Patella, D. Introduction to ground surface self-potential tomography. Geophys. Prospect. 1997, 45, 653-681. [CrossRef]

59. Mauriello, P.; Patella, D. Resistivity anomaly imaging by probability tomography. Geophys. Prospect. 1999, 47, 411-429. [CrossRef]

60. Mauriello, P.; Patella, D. Resistivity tensor probability tomography. Prog. Electromagn. Res. B 2008, 8, 129-146. [CrossRef]

61. Mauriello, P.; Patella, D. Geoelectrical anomalies imaged by polar and dipolar probability tomography. Prog. Electromagn. Res. 2008, 87, 63-88. [CrossRef]

62. Alaia, R.; Patella, D.; Mauriello, P. Application of geoelectrical 3D probability tomography in a test-site of the archaeological park of Pompei (Naples, Italy). J. Geophys. Eng. 2007, 5, 67-76. [CrossRef]

63. Alaia, R.; Mauriello, P.; Patella, D. Imaging multipole self- potential sources by 3D probability tomography. Prog. Electromagn. Res. B 2009, 14, 311-339. [CrossRef]

64. Compare, V.; Cozzolino, M.; Mauriello, P.; Patella, D. Resistivity Probability Tomography Imaging at the Castle of Zena, Italy. EURASIP J. Image Video Process. 2009, 1-9. [CrossRef]

65. Minelli, A.; Cozzolino, M.; di Nucci, A.; Guglielmi, S.; Giannantonio, M.; D’Amore, D.; Pittoni, E.; Groot, A.M. The prehistory of the Colombian territory: The results of the Italian archaeological investigation on the Checua site (Municipality of Nemocòn, Cundinamarca Department). J. Biol. Res. 2012, 85, 94-97. [CrossRef]

66. Compare, V.; Cozzolino, M.; Mauriello, P.; Patella, D. 3D Resistivity probability tomography at the prehistoric site of Grotta Reali (Molise, Italy). Archaeol. Prospect. 2009, 16, 53-63. [CrossRef]

67. Compare, V.; Cozzolino, M.; di Giovanni, E.; Mauriello, P. Examples of Resistivity Tomography for Cultural Heritage Management. In Near Surface 2010 - 16th EAGE European Meeting of Environmental and Engineering Geophysics; European Association of Geoscientists and Engineers (EAGE): Utrecht, Holland, 2010.

68. Cozzolino, M.; di Giovanni, E.; Mauriello, P.; Desideri, A.V.; Patella, D. Resistivity Tomography in the Park of Pratolino at Vaglia (Florence, Italy). Archaeol. Prospect. 2012, 19, 253-260. [CrossRef]

69. Cozzolino, M.; Longo, F.; Pizzano, N.; Rizzo, M.L.; Voza, O.; Amato, V. A Multidisciplinary Approach to the Study of the Temple of Athena in Poseidonia-Paestum (Southern Italy): New Geomorphological, Geophysical and Archaeological Data. Geosciences 2019, 9, 324. [CrossRef]

70. Cozzolino, M.; Caliò, L.M.; Gentile, V.; Mauriello, P.; Di Meo, A. The Discovery of the Theater of Akragas (Valley of Temples, Agrigento, Italy): An Archaeological Confirmation of the Supposed Buried Structures from a Geophysical Survey. Geosciences 2020, 10, 161. [CrossRef] 
71. Cozzolino, M.; Baković, M.; Borovinić, N.; Galli, G.; Gentile, V.; Jabučanin, M.; Mauriello, P.; Merola, P.; Živanović, M. The Contribution of Geophysics to the Knowledge of the Hidden Archaeological Heritage of Montenegro. Geosciences 2020, 10, 187. [CrossRef]

72. Cozzolino, M.; Mauriello, P.; Moisidi, M.; Vallianatos, F. A Probability Electrical Resistivity Tomography Imaging of complex tectonic features in the Kissamos and Paleohora urban areas, Western Crete (Greece). Ann. Geophys. 2019, 62, 13. [CrossRef]

73. Di Giuseppe, M.G.; Troiano, A.; Fedele, A.; Caputo, T.; Patella, D.; Troise, C.; de Natale, G. Electrical resistivity tomography imaging of the near-surface structure of the Solfatara crater, Campi Flegrei (Naples, Italy). Bull. Volcanol. 2015, 77, 27. [CrossRef]

74. Goodman, D. GPR-SLICE. Ground Penetrating Radar Imaging Software, User's Manual; Geophysical Archaeometry Laboratory: Los Angeles, CA, USA, 2004.

(C) 2020 by the authors. Licensee MDPI, Basel, Switzerland. This article is an open access article distributed under the terms and conditions of the Creative Commons Attribution (CC BY) license (http://creativecommons.org/licenses/by/4.0/). 